\title{
JUURNAL.RU
}

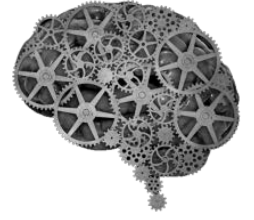

COMPANY GROUP "INTELLEKT"

\author{
Нурлыева А.А, Гайфуллина Д.Т. \\ ФГБОУ ВО Башкирский ГАУ \\ Россия
}

doi: 10.18411/lj2016-6-2-05

\section{Разработка рецептуры итальянских медовых шариков повышенной пищевой ценности с использованием нетрадиционного растительного сырья}

Аннотация: Данная статья посвящена разработке рецептуры итальянских медовых шариков повышенной пищевой ценности с использованием нетрадиционного растительного сырья. Определены органолептические и физико-химические показатели готовой продукции.

Ключевые слова: разработка рецептуры, добавление нутовой муки муки и фруктозы, физико- химические показатели, органолептическая оценка, витамины.

Сохранение здоровья и продление жизни населения Российской Федерации является важнейшей национальной проблемой на современном этапе развития страны. Решение этой проблемы напрямую связано с обеспечением всех возрастных групп населения адекватным и биологически полноценным питанием.

Кондитерские изделия представляют собой большую группу высококалорийных пищевых продуктов, которые пользуются в России все большим спросом. Основной недостаток таких изделий заключается в том, что физиологическая ценность этих продуктов невелика. Они служат в основном источником углеводов и жиров, поэтому их чрезмерное употребление нарушает 
сбалансированность рациона как по пищевым веществам, так и по энергетической ценности. В то же время содержание важнейших микронутриентов (витаминов, макро- и микроэлементов) и пищевых волокон в них, как правило, незначительно.

Поэтому с каждым годом все более актуальной становится разработка рецептур и технологий производства мучных кондитерских изделий с повышенной биологической ценностью, удовлетворяющих принципам здорового питания. Практический интерес представляют продукты, имеющие повышенную пищевую и энергетическую ценность [1].

Исходя из вышеизложенного, целью настоящего исследования явилось повышение пищевой ценности итальянских медовых шариков за счет внесения нутовой муки и заменой сахара на фруктозу.

Нутовая мука обладает уникальным составом, и поэтому считается ценным диетическим продуктом питания. Сегодня наукой доказано, что систематическое употребление в пищу нутовой муки серьезно сокращает риск возникновения сердечно-сосудистых заболеваний, стимулирует деятельность желудочно-кишечного тракта, стабилизирует уровень сахара в крови, предупреждает развитие онкологических заболеваний, нормализует работу печени, способствует растворению камней в почках, укрепляет наши нервную и иммунную системы, заметно снижает уровень холестерина в крови.

Фруктоза широко используется для изготовления не только диетических продуктов, но и лечебных препаратов. Она хорошо укрепляет иммунную систему. На ее основе производят лекарства от сердечных заболеваний и шоковых состояний. Исследования ученых показали, что фруктоза по сравнению с сахаром значительно снижает риск развития воспалительных заболеваний в полости рта, в частности, кариеса. А стоматологи обратили внимание, что желтый налет, образующийся на зубах, намного слабее и лучше удаляется при употреблении фруктозы. Дело в том, что рафинированный сахар 
содержит плотное вещество декстран, а фруктоза состоит из растительных легко разрушающихся соединений.

При оптимизации дозировок нутовой муки и фруктозы в разработке рецептуры итальянских медовых шариков взяли за основу рецептуру итальянских медовых шариков. Согласно рецептуре сначала выпекали контрольные образцы [2].

Далее в опытных образцах пшеничную муку заменяли на нутовую муку в количестве $10,20,30,40,50 \%$. Технология приготовления образцов выпеченного с введением нетрадиционного растительного сырья аналогична технологии приготовления контрольного образца. Исследовали качество готового изделия в зависимости от дозировки нутовой муки.

При приготовлении итальянских медовых шариков нутовую муку вносили при замесе теста в сухом виде в дозировке 10; 20; 30; 40, 50\% к массе муки.

Результаты исследований показали,

Проведенные исследования позволили определить оптимальную дозировку нутовой муки (40\% к массе муки) при производстве хлебобулочных изделий из пшеничной муки

На рисунке 1 указано влияние нутовой муки на влажность итальянских медовых шариков

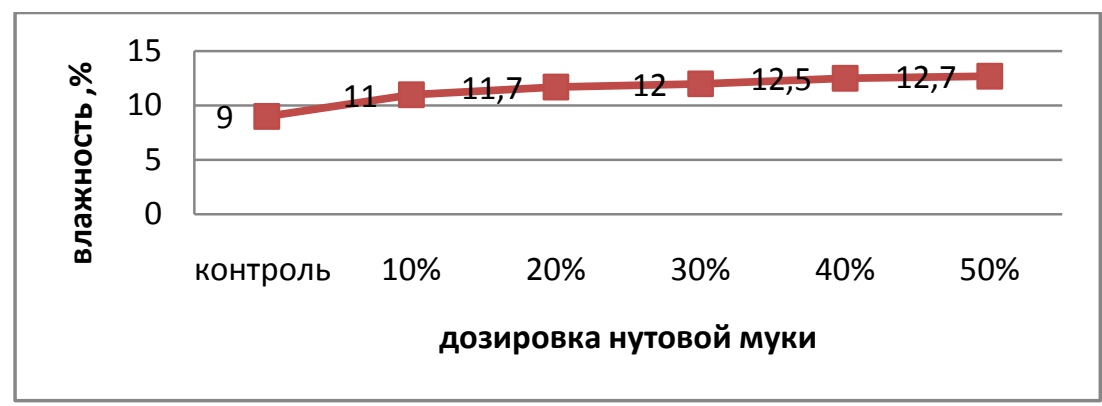

Рисунок 1 Влияние различных дозировок нутовой муки на влажность итальянских медовых шариков

Из рисунка 1 видно что при увеличении дозировки нутовой муки влажность изделия возрастает, это обьясняется тем что массовая доля влаги в нутовой муке больше чем в пшеничной. 
На рисунке 2 приведен график зависимости кислотности от дозировоки нутовой муки

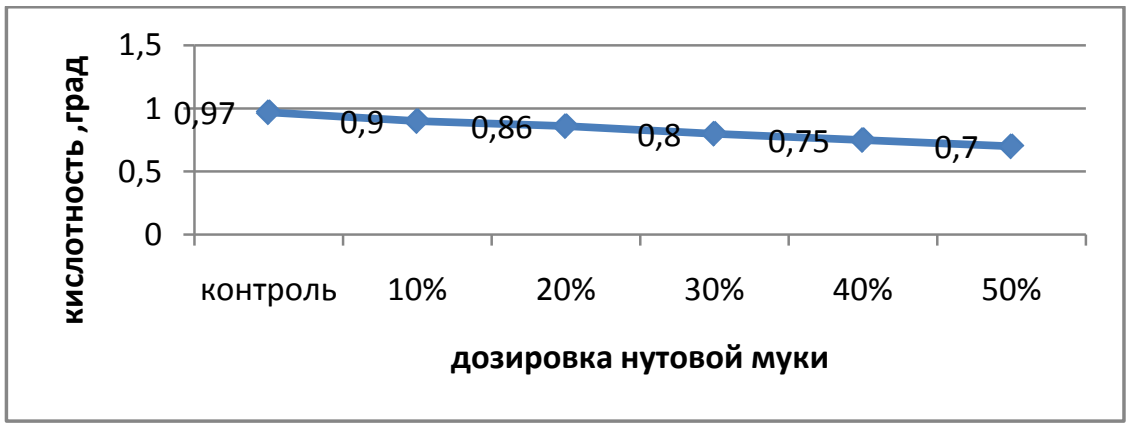

Рисунок 2 График зависимости кислотности от дозировок нутовой муки

Как видно из рисунка 2, при увеличении дозировки нутовой муки кислотность изделий уменьшается. По убыванию титруемой кислотности изделия можно судить о медленном протекание процессов в данной фазе и готовности теста. Как видно из приведенных данных, при внесении нутовой муки отмечается тенденция более медленному уменьшению кислотности в данных образцах по сравнению с контрольным. При уменьшение кислотности вкусовые качества изделий улучшаются.

На рисунке 3 приведен график изменения намокаемости от дозировки нутовой муки.

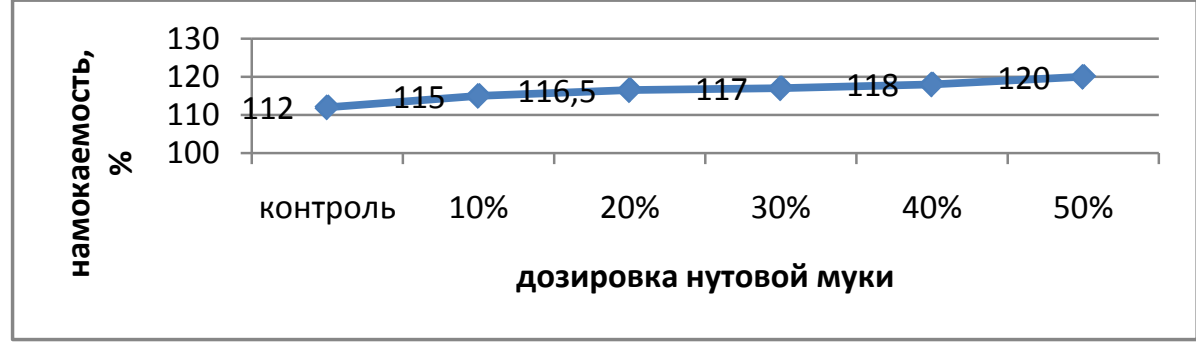

Рисунок 3 Влияние нутовой муки на намокаемость итальянских медовых шариков

Как видно из рисунка намокаемость итальянских медовых шариков повышается с увеличением нутовой муки в изделии. Итальянские медовые шарики становятся более пышными .

Далее в опытных образцах производили 100\% замену сахара на фруктозу. На рисунке 4 представлено изменение массовой доли сахара на изделие. 


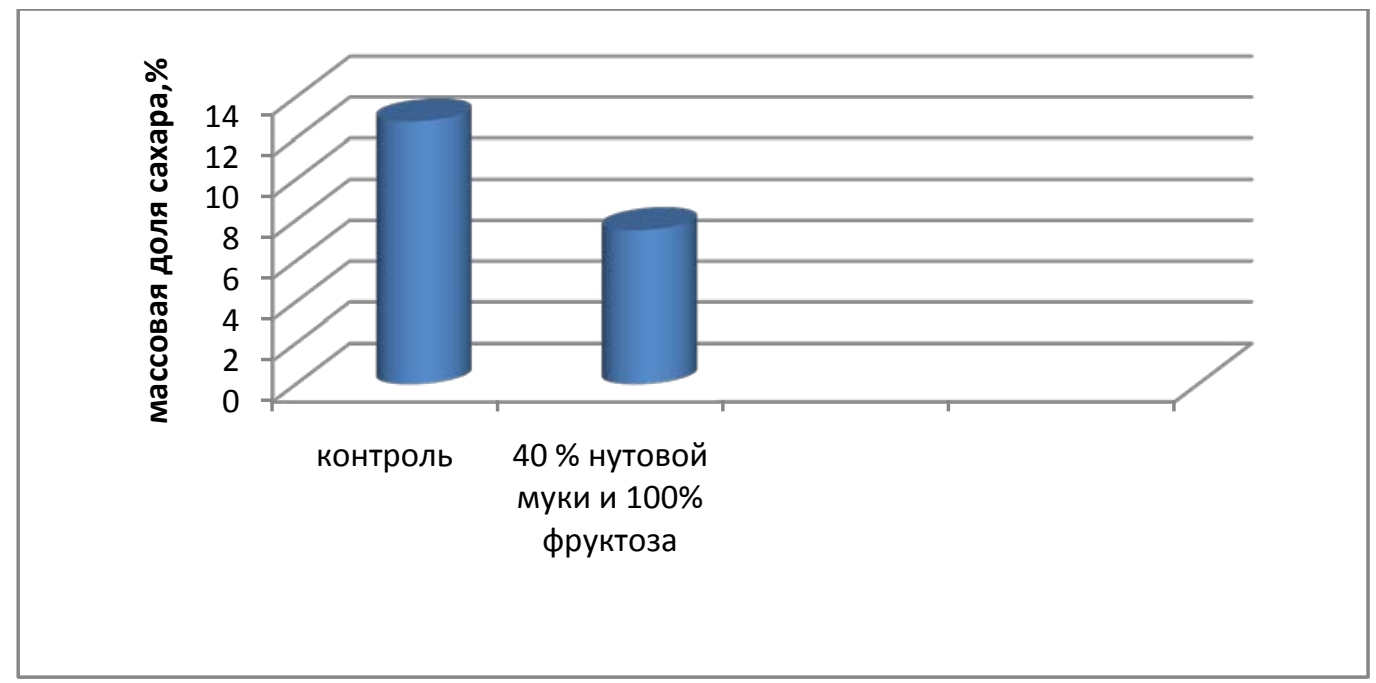

Рисунок 4 Изменение массовой доли сахара в изделии

При полной замене сахара на фруктозу массовая доля сахара значительно уменьшилась. Это связано с тем что вносимый в рецептуру природный сахарозаменитель фруктоза является менее калорийна чем сахар и считается диетическим продуктом.

На рисунке 5 представлено изменение содержание витамина В2

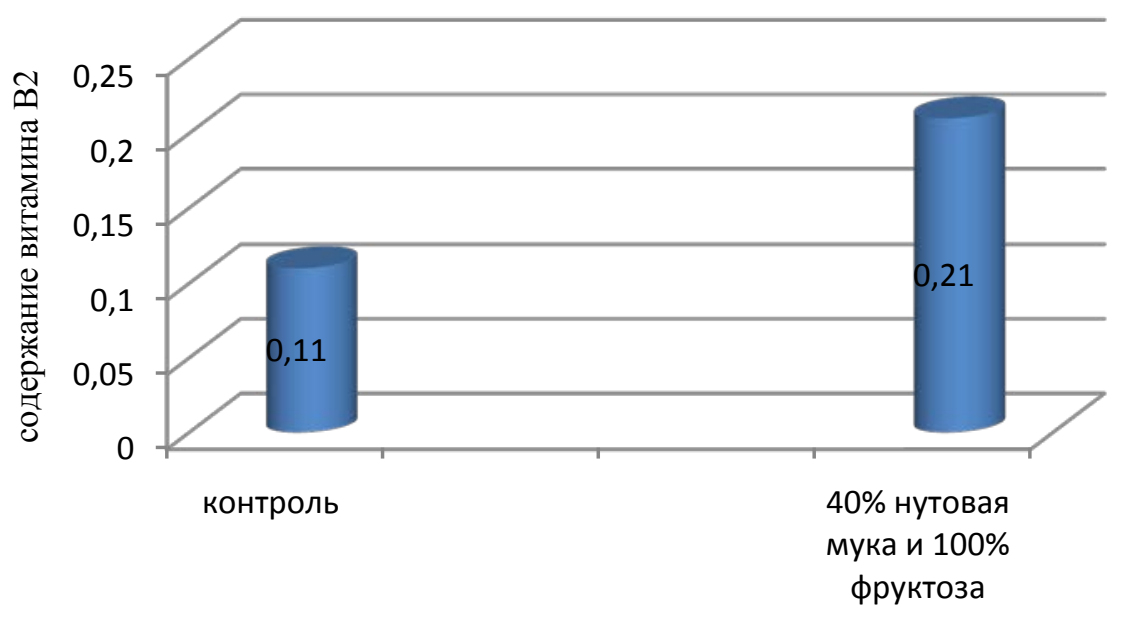

Рисунок 5 Содержание витамина В 2

Как видно из рисунка 5 витамин В2 увеличивается, это связано с тем что нутовая мука богата витамином В2.

На рисунке 6 представлено изменение содержание витамина В6. 


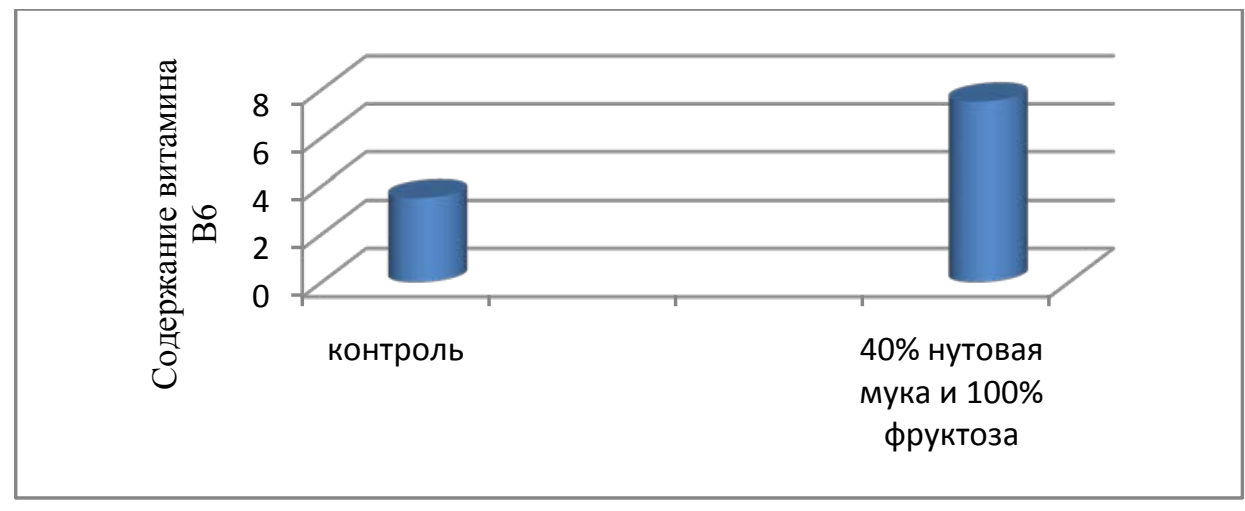

Рисунок 6 Содержание витамина В6

Следовательно, витамин В6 увеличивается за счет нутовой муки, т.к нутовая мука богата витамином В6.

В ходе проделанной работы можно сделать вывод о том, что оптимальной дозировкой нутовой муки в итальянских медовых шариках является 40\% к массе муки, и 100\%-ная замена сахара фруктозой. Рассчитав энергетическую и пищевую ценность медовых шариков можно сделать вывод о том, что медовые шарики с добавлением нетрадиционного сырья растительного происхождения является полезным, обогащенным витаминами и привлекательным для потребителей изделием. Также выяснили, что медовые шарики с добавлением нетрадиционного сырья растительного происхождения по калорийности ниже по сравнению с контрольными образцами, следовательно, данное изделие может использоваться в диетическом и функциональном питании. 


\section{Литература:}

1. Садыгова М.К. Нутовая мука - улучшитель реологических свойств пшеничного теста [Текст] : / М.К. Садыгова, Г.О. Магомедов, И.А. Кибкало, Л.В. Андреева // Хлебопечение России. - 2011. - № 3. - С.23-25.

2. Цыганова Т. Б. Технология и организация производства хлебобулочных изделий [Текст]: учебник / Т. Б. Цыганова. - 3-е изд., стер. - М. : Академия, 2010. - 447 c. 